\title{
THE NATURAL GAS AS A SUSTAINABLE FUEL ATLERNATIVE IN LATVIA
}

\author{
J. Savickis ${ }^{1}$, A. Ansone², L. Zemite*2, I. Bode², L. Jansons², N. Zeltins², \\ A. Koposovs'2, L. Vempere², E. Dzelzitis ${ }^{2}$ \\ 'ITERA Latvija \\ 50 Skanstes Str., Riga, LV-1013, LATVIA \\ ${ }^{2}$ Riga Technical University, \\ Faculty of Electrical and Environmental Engineering, \\ Institute of Power Engineering \\ 12-1 Azenes Str., Riga, LV-1048, LATVIA \\ *e-mail: laila.zemite@rtu.Iv
}

Despite various benefits that the natural gas mobility can provide, CNG (hereinafter compressed natural gas) and LNG (hereinafter - liquified natural gas) filling infrastructure both in Latvia and the Baltic States as a whole is still at the stage of active development. As a result, the natural gas fuelled vehicle fleet comprises less than $1 \%$ of all registered road vehicles in the Baltics, but, with regards to transport and climate policies of the European Union (hereinafter - the EU), it has a significant potential for further growth.

In order to estimate the perspectives of mobility of natural gas, including bioCNG and liquified biomethane (hereinafter - LBM), CNG has been chosen and analysed as a possible alternative fuel in Latvia with its environmental and economic benefits and payback distance for CNG vehicles compared to petrol and diesel cars. The review of various types of CNG filling stations is also presented, along with information on operating tax rates and currently registered vehicles divided by types of fuel in Latvia.

It was established that with the Latvian fuel price reference of the late 2020, exploitation of CNG-powered vehicle was by $24 \%$ cheaper per kilometre in comparison with diesel and by $66 \%$ cheaper in comparison with petrol vehicles. CNG vehicles have smaller operational taxes, since they are based on carbon dioxide (hereinafter $-\mathrm{CO}_{2}$ ) emissions, which are lower for CNG-powered vehicles. Calculation results also indicate that CNG vehicle payback time may fall within the warrant period, if at least 57650 kilometres as an alternative to a petrol vehicle or 71531 kilometres as an alternative to a diesel vehicle are driven by it.

Keywords: Alternative fuels, CNG, filling stations, Latvia, LNG, transport decarbonisation, transport infrastructure. 
The transport, and particularly road transport, is one of the most significant fossil fuel dependent segments of the national economies across Europe. Oil dependency of all segments of the transport sector makes it the single biggest source of greenhouse gas emissions (hereinafter - GHG) in the EU as well. Road transport is responsible for about $73 \%$ of total transport GHG emissions, as more than 308.3 million road vehicles in Europe are over $90 \%$ reliant on conventional types of oil-based fuels (diesel, petrol etc.) [1]-[3].

At the same time, if viewed from the sustainability standpoint, there are viable alternatives to traditional oil-based fuels, which can be used effectively already today. Among them, natural gas in a form of $\mathrm{CNG}$ and LNG, along with admixtures of various renewables gases (hereinafter - RG) should be pointed out as one of the most promising option. Natural gas emits approximately $6 \%$ to $11 \%$ less GHGs than petrol throughout the fuel life cycle. The GHG emissions impacting the CNG and LNG life cycle are predominately the result of productionphase fuel leakage. When comparing the life cycle emissions of the two types of the natural gas - CNG and LNG, a reasonable statement could be made that they are nearly identical. However, production of CNG uses less petroleum and emits slightly fewer GHGs than LNG because compressing natural gas requires less energy than liquefying it [4].

The main driver for more active and widespread use of natural gas as a transport fuel is its chemical properties. Natural gas has a high calorific value, with significantly less GHG than conventional fuels. Natural gas used in road transport is the same as used for electricity production, heating or cooking. The main component of natural gas is methane - the simplest hydrocarbon [5]. Methane has a high-octane rating (130), which is a standard measure of the performance of an engine or aviation gasoline, and a low boiling point $\left(-161.5^{\circ} \mathrm{C}\right)$, making it a usable fuel for spark ignition internal combustion engines [6]. Similar to petrol and diesel, natural gas has a low ignition limit, or $4.3-15.2 \%$ by volume in the air, which reduces the risk of accidental ignition. At the same time, high-octane rating allows for a higher degree of compression in the engines, thus providing more engine power. The combustion properties of natural gas differ significantly from diesel and petrol, and it burns cleaner.

Another significant property of natural gas is its relative density: $0.55-0.70 \mathrm{~kg} / \mathrm{m}$ [7]. Due to the fact that natural gas is lighter than air, it quickly disperses into the atmosphere in case of leakage. Diesel and petrol, on the other hand, are liquid substances and, if they leak, there is an increased risk of fire or even long-term environmental pollution.

Price advantage of natural gas, including $\mathrm{CNG}$, over conventional fuels should also be pointed out. In most countries, natural gas is much cheaper than the equivalent amount of conventional fuel, even after the cost of transportation and treatment - liquefaction or compressing, is added to the price of natural gas itself. Petrol and diesel have to undergo a complex refining process until they reach filling stations, while natural gas has to be treated less. The price of natural gas is also less subjected to price fluctuations, and the resource itself is more evenly distributed throughout the world [8].

Although natural gas as a primary energy resource has been rather cheap in a past decade, installation of transport and 
distribution infrastructure and filling stations still remains costly. Therefore, in almost all countries where $\mathrm{CNG}$ and $\mathrm{LNG}$ filling infrastructure is developed, investors are offered various development promotion programmes: loans, subsidies, tax rebates, exemptions from import duties on machinery and equipment. Support mechanisms are needed at the early stages of development to stimulate investor interest. In Canada, for example, reducing investment in CNG filling infrastructure has led to the collapse of the industry as a whole [9].

The cost of setting up a CNG infrastructure can vary considerably depending on a size of a filling station, its capacity and the type of CNG filling. Costs can be significantly reduced by setting up a combined CNG and LNG (hereinafter - L-CNG) filling station, especially in regions where such a decision is economically viable, or adding CNG filling option to existing service station [8].

\section{THE MAIN TYPES OF THE NATURAL GAS FUELING STATIONS}

In general, there are several types of CNG filling systems: buffer, cascade direct and portable (mobile) filling. In buffer type filling stations, $\mathrm{CNG}$ is stored in one highpressure tank. In cascade-type filling stations, $\mathrm{CNG}$ is mainly stored in three tanks. These are called low, medium and high-

\subsection{Buffer-Type Filling System}

Buffer-type CNG filling systems are usually known as "slow filling", while cascade-type CNG filling systems - "fast filling". Slow filling systems are mostly used in households or small businesses with small CNG vehicle fleet, where filling speed is not critically important. Slow filling systems are suitable for a night time pressure tanks [10]. Direct filling CNG stations are refuelled directly by means of a compressor, while portable filling stations can be connected to and disconnected from the natural gas grid relocated without problems.

use, as they switch off automatically when the filling cycle is complete. Fast filling stations, on the other hand, are suitable for more "traditional fuel like" CNG filling, thus increasing customer convenience. For fast CNG filling systems, vehicle filling time is about the same as for filling of petrol or diesel cars [11].

\section{Time-Fill Station}

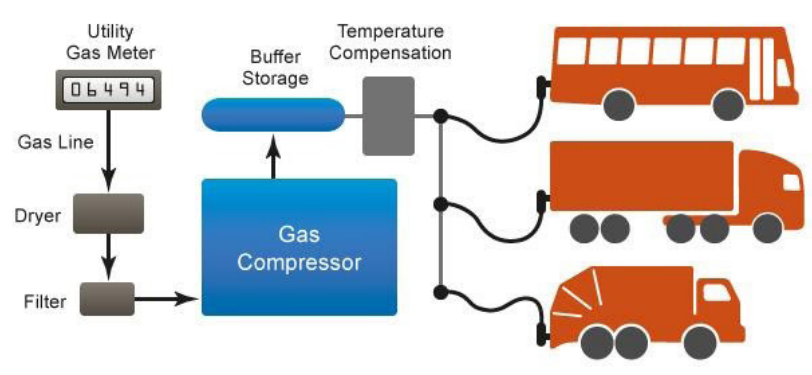

Fig. 1. Buffer-type filling system. Source: afdc.energy.gov 
Natural gas for CNG filling is usually taken from the medium pressure distribution gas system, where pressure is lower than 4 bar. The CNG storage system at the filling station consists of several tanks, the size of which can vary from 50 to 100 litres or more. The storage system maintains more

\subsection{Cascade-Type Filling System}

In cascade-type filling systems, the natural gas storage is divided into three tanks: low, medium and high pressure. Each of these tanks consists of several storage cylinders. In this storage system, the tank cylinders are installed in ascending order.

During fast filling, the $\mathrm{CNG}$ cylinder of the vehicle is initially connected to the low-pressure tank of the filling station. As the pressure in the tank drops and it rises pressure than the car system to allow gas to flow to it. The buffer-type CNG filling stations operate in the range of 20.5-25 MPa, while pressure in cars on-board cylinder is $20 \mathrm{MPa}$. In this type of storage, all reservoir cylinders are connected, and pressure in them are held equally high among them.

in the car cylinder, the gas flow decreases. As the gas flow rate decreases to a previously stated value, the system automatically switches to a medium pressure tank, then to a high-pressure tank to complete the vehicle refill. Switching from one tank to another is provided by a microprocessor algorithm, as well as sensors for measuring the mass flow from all three tanks. The microprocessor controls the electronic sequence valves [12].

Fast-Fill Station



Fig. 2. Cascade-type filling system. Source: afdc.energy.gov

The cascade-type filling systems provides a "more complete" filling compared to buffer-type systems. In addition, when the compressor is automatically switched on to fill the tanks, it first fills the highpressure tank, then switches to the mediumpressure tank and then to the low-pressure tank. This ensures that the high-pressure

\subsection{Combined-Type Filling System}

Combined-type filling systems can be used for both fast and slow filling. For example, the slow-filling option allows vehicles to be left to fill overnight, but, at the same time, fast-filling options can also tank is maintained at maximum pressure at all times, ensuring that vehicles will always be filled with the maximum amount of the natural gas available. Proper specification of compressor capacity and cascade storage volume is necessary to ensure that a $\mathrm{CNG}$ filling station can fill certain types of vehicles, such as buses, trucks, etc. [10].

be used, making fleet filling more flexible. Combined-type CNG filling stations are usually more expensive than the types of filling stations mentioned above. 


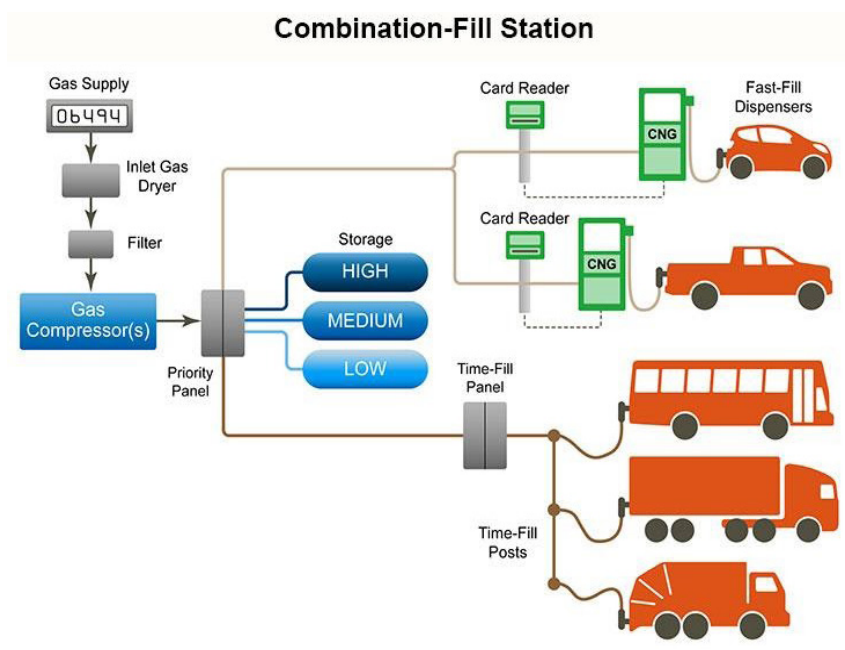

Fig. 3. Combined-type filling system.

Source: afdc.energy.gov

Although such filling stations can also be a source of additional income, as service provider's own fleet can be connected to a slow filling system and left there overnight, with fast-filling system made available to all in need of fast and convenient CNG filling at all times [13].

\subsection{Local (Household) CNG Filling Installations}

In order to avoid building of large filling stations, it is also possible to install a small local filling station in households and small businesses as well. The installation of such a filling station is rather simple, it is compact without taking up much space and it is easy to use. Unfortunately, such small

\subsection{Portable CNG Filling Stations}

There are also portable CNG filling station solutions available on a market. Such stations can be used for both temporary and permanent filling, and contain all the same elements as stationary filling stations. Depending on the station configuration, both $\mathrm{CNG}$ and LNG can be used for filling. The main advantage of mobile sta-

\subsection{LNG and L-CNG Filling Stations}

In the Eastern Baltic, the percentage of alternatively fuelled road vehicles remain rather low, with the natural gas-powered filling stations are only designed for slow filling option. They usually have a filling rate of $2 \mathrm{~m}^{3} / \mathrm{h}$ to $5 \mathrm{~m}^{3} / \mathrm{h}$, and a maximum rate of $20 \mathrm{~m}^{3} / \mathrm{h}$. Like other filling stations, it has a small tank of about $0.5 \mathrm{~m}^{3}$ to reduce compressor load fluctuations [14].

tions is their mobility and wide range of applications, for example, they can replace stationary stations during their maintenance or repair. The filling station can be used on construction sites to fill vehicles. Often, mobile filling stations are powered by natural gas engines; as a result, they do not require an external energy source [14].

road vehicle fleet in Latvia being equal to about a few hundred. Currently, there are only two LNG filling stations in the Baltic 
States, both located in Estonia, and 9 filling stations located in Finland. It is important to mention that most of these filling stations can serve both CNG and LNG fuelled vehicles. L-CNG filling stations allow filling CNG for light and LNG for heavy-duty vehicles. Such filling stations have lower capital and operating costs than separate LNG and CNG filling stations of similar capacity [15].

A typical LNG filling station consist of the following components and systems: cryogenic storage tank for $\mathrm{LNG}$, with typical volume of $60-70 \mathrm{~m}^{3}$, acryogenic submerged centrifugal pump skid, weights and measures certified dispensers for LNG, connected to a payment system, LNG cooling system using patented equipment to deliver cold LNG and eliminate the risk of natural gas being released to atmosphere, the natural gas and leak detection equipment, and a complete PLC control system supporting remote access.

In L-CNG filling stations, the following technical elements must be present: a cryogenic storage tank for LNG, cryogenic reciprocating pumps, vaporizers for deliv- ery of gaseous natural gas, odorizing unit - a safety feature that makes it possible to detect leakage, dispensers for $\mathrm{CNG}$, and a complete PLC control system supporting remote access.

LNG is used as a raw material in L-CNG filling stations. $\mathrm{LNG}$ is stored at a very low temperature, about $-163{ }^{\circ} \mathrm{C}$, at a pressure of 1 bar. 1 litre of LNG at a pressure of 1 bar contains approximately 600 litres of the natural gas.

In a nutshell, L-CNG filling stations are advantageous for several reasons. They increase a number of existing and future CNG filling stations, and allow setting up CNG filling stations in places, where the natural gas connection is not available, or its construction is expensive. L-CNG filling stations sell high-quality $\mathrm{CNG}$ due to the stability of the natural gas properties and efficient filling of CNG fuel tanks due to lower temperature normally provided by the L-CNG system. The lower the inlet gas temperature, the lower the storage temperature of the final product and the correspondingly larger amount of CNG can be stored at the same pressure [15], [16].

\section{USAGE OF NATURAL GAS AS TRANSPORT FUEL IN LATVIA}

The EU has set ambitious targets not only for energy, but also for transport sector decarbonisation, and quite a few directives and regulations have been adopted to promote it. One of the most important ones - Directive 2014/94/EU requires the EU Member States to ensure, through their national policy frameworks, that an adequate number of publicly available CNG filling stations are established by 31 December 2020 to allow CNG-powered vehicles to circulate in urban / suburban agglomerations and other densely populated areas, and, where appropriate, in net- works designated by the Member States. It is also necessary to provide a policy framework for the establishment of an adequate number of publicly available CNG filling stations by 31 December 2025, at least on the existing TEN-T core network, in order to ensure that $\mathrm{CNG}$-powered mechanical vehicles can circulate throughout the EU. The same regulatory principle is applied to LNG filling availability as well [17].

Despite modern and robust natural gas transportation and distribution infrastructure, which allows establishing CNG filling stations in more than a half of the territory 
of Latvia [18], the current stage of the natural gas mobility in our country is not well established yet. In order to fulfil requirements outlined in Directive 2014/94/EU, CNG filling stations should be opened in almost all major cities and towns of Latvia, where the natural gas network is available. These locations include but are not limited to Riga, Liepaja, Jelgava, Valmiera, Bauska, Rezekne, Jekabpils and Daugavpils.

The Latvian state industry standard LV NS GS 06-2006/A1: 2009 "Natural Gas Filling Stations and Filling Equipment" distinguishes two types of filling: the natural gas filling station and car filling equipment. The natural gas filling station is intended for fast (commercial) filling into cylinders that are directly connected to the vehicle. The car refuelling equipment is intended for slow (non-commercial) refuelling of vehicles without supervision. It has no storage pressure vessel and under standard conditions the flow rate does not exceed $20 \mathrm{~m}^{3} / \mathrm{h}$, with a maximum gas capacity of $0.5 \mathrm{~cm}^{3}$ and a maximum gas outlet pressure of 26 MPa [19].

The construction of the natural gas filling stations is subject to strict norms, for example, when installing a natural gas filling station with a total volume of assembled gas above $500 \mathrm{~m}^{3}$, the minimum distance to buildings and structures that cannot be considered as part of the filling station must be at least $50 \mathrm{~m}$ [19].

For $\mathrm{CNG}$ filling, the relevant factor is the timing, which depends on inlet gas pressure, buffer tank volume, filling column permeability and compressor capacity. The filling time is reduced, if the vehicle is filled from the buffer tank. It is also reduced by using a suitable filling device connection cable with the appropriate diameter: natural gas vehicle 1 (diameter $8 \mathrm{~mm}$ ) for cars and minibuses, and natural gas vehicle 2 (diameter $12 \mathrm{~mm}$ ) for trucks and buses. Also, filling time can be reduced by the number of filling modules in the filling station and their efficient use, as insufficient buffer tank volume increases the filling time [15], [16].

In order to promote decarbonisation of the transport sector and reduce the negative environmental impact of its GHG emissions, as well as to transpose the requirements of Directive 2014/94/EU in Latvia, "The Development Plan for Alternative Fuels 2017-2020" (hereafter - Plan) was adopted. Its aim was to identify the necessary trends of research and analysis that would lead to the development of further policies on the introduction of alternative fuels in certain transport sectors to ensure their sustainability. The task of the Plan was to identify the current situation in the field of alternative fuels and to determine further steps for the introduction and promotion of alternative fuels in Latvia [20], [21]. The Plan, among other, requires, for example, that by 31 December 2020, at least five publicly available CNG filling stations be established in Latvia, and by 31 December 2019, a review of tax policy, including the level of excise duty on natural gas as transport fuel, be performed. The first requirement, however, was fulfilled only in early 2021.

The history of CNG filling infrastructure in Latvia is still a short one, as the first CNG filling station in Latvia was opened in Jekabpils in 2019. Such a location of the filling station was chosen by the fuel retailer JSC "Virši-A" due to a fact that Jekabpils public transportation company obtained public buses that used CNG as fuel. Consequently, Jekabpils was the first municipality in Latvia to use CNG in passenger transport. Currently, its bus fleet includes 7 CNG-powered buses. The buses were purchased within the framework of the EU support project "Development of Environmentally Friendly Public Transport (Buses)" 
of the priority axis "Transition to a LowCarbon Economy in All Sectors" of the programme "Growth and Employment". The total amount of funding provided was EUR 1792 053, EUR 1398250 of which was co-funded from the EU sources [22]. Currently, the procedure is under way in order to acquire $35 \mathrm{CNG}$ fuelled buses for public transportation company in one of the largest
Latvian municipalities - Daugavpils [23].

In spring of 2021, there were 6 public CNG filling stations in operation in Latvia: Riga, Babite, Jekabpils, Rezekne, Olaine and Broceni, all owned and operated by JSC "Virši-A" [24]. During the same period, more than $20 \mathrm{CNG}$ filling stations were in operation in Estonia, and close to $10-$ in Lithuania.

\section{CNG AND LNG DEVELOPMENT POTENTIAL IN LATVIA}

Electric mobility has long been considered the energy of the future for transport, but its use in road transport still has its drawbacks. Given the availability of the natural gas technologies and the good prospects for achieving transport decarbonisation targets, they are often preferred, for example, in transport in large cities of several European countries (Germany, Italy, Switzerland) and the United States. Thanks to positive environmental performance, including $\mathrm{GHG}$ savings, they are also entering maritime transport, opening up new global markets for the wider and more intensive use of the natural gas resources worldwide [25], [26].

According to the requirements of Directive 2014/94/EU, in 2025 CNG filling stations on motorways must be located every 150 kilometres. This means that in Latvia it is necessary to build such filling stations in all major cities where natural gas is available.

Additional incentives for the use of $\mathrm{CNG}$ as a transport fuel can be given by vehicle operating tax rates. In Latvia, for vehicles registered for the first time after 31 December 2008, the operating tax rate is applied depending on the amount of $\mathrm{CO}_{2}$ emitted per kilometre (Table 1).

Table 1. Operating Tax Rates per Year from 1 January 2019 [27]

\begin{tabular}{|l|l|l|l|}
\hline \multicolumn{2}{|l|}{$\begin{array}{l}\text { For vehicles with an engine capacity not exceeding } \\
3500 \mathrm{~cm}^{3} \text { (inclusive) }\end{array}$} & $\begin{array}{l}\text { For vehicles with an engine capacity exceeding } 3500 \\
\mathrm{~cm}^{3}\end{array}$ \\
\hline $\mathrm{CO}_{2}$ emissions (g) per km & Rate (EUR) & $\mathrm{CO}_{2}$ emissions (g) per km & Rate (EUR) \\
\hline Up to 50 & 0 & Up to 50 & 300 \\
\hline $51-95$ & 12 & $51-95$ & 312 \\
\hline $96-115$ & 48 & $96-115$ & 348 \\
\hline $116-130$ & 84 & $116-130$ & 384 \\
\hline $131-155$ & 120 & $131-155$ & 420 \\
\hline $156-175$ & 144 & $156-175$ & 444 \\
\hline $176-200$ & 168 & $176-200$ & 468 \\
\hline $201-250$ & 264 & $201-250$ & 564 \\
\hline $251-300$ & 408 & $251-300$ & 708 \\
\hline $301-350$ & 552 & $301-350$ & 852 \\
\hline 351 and more & 756 & 351 and more & 1056 \\
\hline
\end{tabular}


CNG is not only cheaper as a fuel, but the owner of such a vehicle would also have to pay a lower operating tax compared to the same car model with diesel or petrol engine.

The construction of an LNG terminal in Latvia could also contribute to the faster development of both LNG and CNG filling station networks. The LNG terminal would open the possibility to build L-CNG type filling stations as well.

In 2019, as a result of negotiations between industry and policy makers, the Cabinet of Ministers of the Republic of Latvia drafted an order "Amendments to Cabinet Order No. 202 of 25 April 2017 “On Alternative Fuels Development Plan
2017-2020"', which, inter alia, provides an assessment of possible solutions to ensure the application of a reduction in excise duty on natural gas used as fuel in transport, if biomethane is added [21]. In the most optimistic case of the alternative fuel development in Latvia reflected in the plan, $\mathrm{CNG}$ and LNG combined would account for more than any other transport fuel in fleet, including diesel and gasoline, by 2050, but for fulfilment of such a high ambition much stronger and politically coordinated support to RG industry, first and foremost domestic biomethane production and its end use both locally and by means of natural gas grid, must be provided.

Table 2. Possible Alternative Fuel Development in the Latvian Transport Sector (2025-2050, \%)

\begin{tabular}{|l|c|c|c|c|}
\hline \multirow{2}{*}{ Fuel } & \multicolumn{3}{|c|}{ Year } \\
\hline & 2025 & 2030 & 2040 & 2050 \\
\hline Diesel & 67.2 & 64 & 34.4 & 23.1 \\
\hline Gasoline & 20.4 & 12.1 & 12.8 & 10.6 \\
\hline LPG & 7.1 & 13.9 & 7 & 6.4 \\
\hline LNG & 0.5 & 0.7 & 2 & 2.1 \\
\hline CNG & 2.5 & 4.5 & 19.9 & 30.2 \\
\hline Biodiesel & 0.2 & 0.2 & 10.4 & 12.9 \\
\hline Bioethanol & 0.7 & 0.4 & 0.5 & 0.4 \\
\hline Biomethane & 0 & 1 & 1.9 & 0 \\
\hline Hydrogen & 0 & 0 & 0 & 0 \\
\hline Electric cars & 1 & 2.5 & 10.2 & 13.2 \\
\hline Electric public transport & 0.5 & 0.6 & 0.9 & 1 \\
\hline
\end{tabular}

Latvia admits that the absence of a national policy plan has jeopardised the use of natural gas in transport. It has established targets for the deployment of CNG refuelling points accessible to the public. The targeted number of CNG refuelling points could support a significant increase in CNG vehicles. As indicated in the national policy framework, Latvia also has no plans for the deployment of LNG refuelling points in its ports [21].

However, at the moment Latvia lacks any elements of the LNG import infrastructure, although several propositions to build a terminal in different locations were presented over the course of the last decade. The first proposition is related to Kundzinsala Southern Project. According to information of the Freeport of Riga, LNG terminal with an area of 34 hectares was planned to be built on the island of Kundzinsala, which is mainly used as a maritime trade related industrial area. Instead of planning connection to the natural gas transmission 
network, developers of Kundzinsala LNG terminal made a decision in favour of connection to the natural gas distribution grid. Project team requested and received technical regulations from the Latvian natural gas distribution system operator to make a connection to the natural gas distribution system in Riga. In order to make a connection, the LNG terminal operator was obligated to build the following elements of infrastructure and technical equipment: supply pipeline from the terminal to the distribution system, a gas connection point and a metering station with a gas chromatograph [28]. The expected business areas of the terminal were outlined as follows: bunkering, trade of $\mathrm{LNG}$, including deliveries to road transport filling stations and alternative distribution networks, and injection of regasified natural gas into the Latvian natural gas distribution network [26].

As an alternative, a proposal to construct LNG terminal in Skulte, the Northwestern part of Riga Gulf, emerged. Skulte project was presented as a floating regasification unit without LNG storage tanks, but with a direct pipeline connection to the Incukalns underground gas storage (hereinafter - Incukalns UGS) facility. Unfortunately, this type of LNG terminal is not designed to supply unregasified LNG, which could be transported further by trucks, for example, to L-CNG filling stations. The Skulte project developers state that the project has unique geographic, economic and technological advantages over any other LNG import terminal proposal of comparable capacity. A fact that LNG cold storage facility, which usually takes up to $70-80 \%$ of LNG import terminal building expenses, is not needed was presented as its obvious strong point. Instead, the developers made an assumption that Incukalns UGS will serve as a permanent storage for all delivered natural gas resources, and direct high-pressure pipe- line connection between the storage and the LNG terminal will be built. Despite the fact that preliminary costs of the project are not yet known, the developers announced that total estimated investments would be at least 3 times less than for any other LNG terminal type of comparable capacity with LNG cold storage option [29], [26].

In addition, biogas can be used to reduce $\mathrm{CNG}$ and $\mathrm{LNG} \mathrm{CO}_{2}$ emissions further. A positive factor for the use of biogas in internal combustion engines is lower toxicity of exhaust gases. Emissions of carbon monoxide, hydrocarbons and nitrogen oxides are much lower than for diesel or petrol [30], [31]. To use biogas in car engines, it must first be cleaned of excess ballast $\mathrm{CO}_{2}$ and hydrogen sulphide, which causes metal to rust. Excess $\mathrm{CO}_{2}$ in biogas also reduces engine power. About $2 \mathrm{~m}^{3}$ of biogas is equivalent to 1 litre of liquid motor fuel. If biogas is upgraded to biomethane level and compressed, bioCNG provides clean fuel for all types of road vehicles.

The statistics show that the dynamics of the biomethane production with its subsequent conversion into LBM has demonstrated a significant upward pattern in the EU between 2018 and 2020. In this period, a number of biomethane plants have increased by $51 \%$, from 483 in 2018 to 729 in 2020 . There are currently eighteen countries producing biomethane in Europe, with Germany having the highest share of biomethane production plants (232), followed by France (131) and the UK (80) [32].

In the Baltic States, upgrading of the biogas to biomethane level with subsequent injection into the natural gas transportation or distribution grids has not been developed yet. However, at least Latvia with 59 existing biogas plants and 17 of them being located 10 or less km away from the natural gas distribution grids could benefit both from biomethane production and local sales 
(where CNG filling stations and/or smallscale biomethane liquifying facilities are installed onsite) and injection of the biomethane into the natural gas networks [33].

Moreover, in this decade the EU production of LBM is set to increase by factor of ten. The EU LNG heavy-duty transport is expected to reach 280.000 units in the same period. Using a $40 \%$ LBM mix with LNG will help reduce the $\mathrm{CO}_{2}$ emissions from those trucks by $55 \%$. In the shipping sector, $50 \%$ of large container vessel orders today are LNG fuelled or ready for conversion to LNG. $20 \%$ of LBM mix in maritime transport would reduce $\mathrm{CO}_{2}$ emissions by up to $34 \%$.

\section{METHODOLOGY FOR EVALUATION OF CNG AS TRANSPORT FUEL IN LATVIA}

\subsection{Natural Gas in the Latvian Transport Fuel Mix}

In Latvia, approximately $94 \%$ of all vehicles use petrol and diesel as fuel [34], and Table 3 shows the most commonly used transport fuel types in our country. It does not include data on rarely used fuels such as gas generator, diesel combined with natural gas, etc. Thus, it indicates that only around $0.04 \%$ of all road transport vehicles in Latvia use natural gas as primary or secondary fuel.

Table 3. Number of Registered Vehicles as of 1 October 2020 [34]

\begin{tabular}{|l|c|c|c|c|c|c|c|c|}
\hline \multirow{2}{*}{ Fuel type } & \multicolumn{2}{|c|}{ Heavy duty } & \multicolumn{2}{|c|}{ Vehicle } & \multicolumn{2}{c|}{ Buses } & \multicolumn{2}{c|}{ Total } \\
\hline & Quantity & $\%$ & Quantity & $\%$ & Quantity & $\%$ & Quantity & $\%$ \\
\hline Petrol & 2761 & 3.0 & 227639 & 30.7 & 21 & 0.5 & 230421 & 27.47 \\
\hline Diesel & 88850 & 95.3 & 465694 & 62.8 & 4270 & 99.0 & 558814 & 66.62 \\
\hline Electricity & 18 & 0.0 & 1031 & 0.1 & 8 & 0.2 & 1057 & 0.13 \\
\hline Petrol and gas & 868 & 0.9 & 25115 & 3.4 & 4 & 0.1 & 25987 & 3.10 \\
\hline Petrol and LPG & 593 & 0.6 & 21294 & 2.9 & 2 & 0.0 & 21889 & 2.61 \\
\hline Petrol and natural gas & 15 & 0.0 & 183 & 0.0 & 0 & 0.0 & 198 & 0.02 \\
\hline Natural gas & 62 & 0.1 & 81 & 0.0 & 7 & 0.2 & 150 & 0.02 \\
\hline Natural gas and LPG & 15 & 0.0 & 14 & 0.0 & 0 & 0.0 & 29 & 0.00 \\
\hline Total & 93229 & $100.0 \%$ & 741292 & $100.0 \%$ & 4312 & $100.0 \%$ & 838833 & $100.0 \%$ \\
\hline
\end{tabular}

Such a low indicator signals that there is significant potential for CNG use in all segments of the Latvian transport sector. By increasing the number of vehicles using natural gas, it would also be possible to reduce the total consumption of oil-based fuels.

\subsection{Methodology for Evaluation of CNG Effectiveness}

In order to estimate the economic performance of $\mathrm{CNG}$ in comparison to traditional fuels - diesel and petrol, calculations were made to determine the cost per kilometre, as well as the time period in which the purchase of a private CNG-powered vehicle would pay off.

As part of this study, three SEAT passenger cars were used as a practical reference. The empirical evaluation took into 
account investment costs and fuel costs, but maintenance costs were not evaluated due to the similarities of all chosen models. Three chosen models were equipped with different engine types: the first - with a compressed natural gas-petrol engine, the second - with a petrol engine and the third with a diesel engine. The main characteristics of the three models are summarised in Table 4.

Table 4. The Main Technical Parameters and Prices (December, 2020) [35]

\begin{tabular}{|l|c|c|c|c|}
\hline Model & Power, $\mathrm{kW}$ & Fuel type & Fuel consumption, $1 / 100 \mathrm{~km}$ & Price, EUR \\
\hline SEAT LEON 1.5 TGI MAN-6 & 96 & Petrol/CNG & 3.8 & 18700 \\
\hline SEAT LEON 1.5 TSI MAN-6 & 96 & Petrol & 5.0 & 17400 \\
\hline SEAT LEON 1.6 TDI MAN-5 & 85 & Diesel & 4.2 & 18100 \\
\hline
\end{tabular}

The calculation takes into account the limiting factor, which in this case is a warranty period of the vehicle (5 years), during which no more than $100,000 \mathrm{~km}$ may be driven. This means that a vehicle that uses $\mathrm{CNG}$ as a primary fuel must demonstrate, within the specified limitations, that it is more cost-effective than the use of two conventional fuel alternatives.

This part of the calculation does not consider the case, when $\mathrm{CNG}$ fuelling takes place in a private filling point - it relates only to publicly available filling stations. Prices for $\mathrm{CNG}$ and conventional fuels were taken from the specific fuel retailer "Virši-A", as it is the only fuel trader in Latvia currently selling CNG along with traditional oil-based fuels. Fuel price comparison for the three engine types is shown in Table 5.

Table 5. Fuel Prices in Latvia (December, 2020)

\begin{tabular}{|l|c|}
\hline Fuel type & Price for one-unit kg or l (EUR) \\
\hline CNG & 0.90 \\
\hline Diesel & 1.014 \\
\hline Petrol E95 & 1.135 \\
\hline
\end{tabular}

In order to perform calculation, it is necessary to determine the cost per kilometre using different types of fuel. Equation (1) is used for the calculations:

$C_{k m}=0.01 \cdot F \cdot P$,

where

$C_{k m}$ - cost per kilometre, EUR/km;

$F$ - fuel consumption, 1/100 km;

$P$ - fuel price, EUR/l.

Then, using Eq. (2), is possible to calculate by how much CNG is cheaper per kilometre, comparing to diesel and petrol:

$$
\left.P_{d i f}=\left(C_{C N G k m}-C_{F k m}\right) C_{C N G k m}\right) \cdot 100 \text {, }
$$

where

$P_{d i f}$ - difference on how much other fuels are more expensive than $\mathrm{CNG}, \%$;

$C_{C N G k m}$ - cost per kilometre for a specific fuel type (diesel or petrol), EUR/km;

$C_{F k m}-$ cost per kilometre for a specific fuel type (diesel or petrol), EUR/km.

Equation (3) helps calculate the mileage by fuelling for the same amount of money EUR 10:

$M=10 P \cdot 100 F$,

where

$M$ - mileage, $\mathrm{km}$;

$P$ - fuel price, EUR/1;

$F$ - fuel consumption, $1 / \mathrm{km}$. 
In addition, the payback period of vehicles is to be calculated using Eq. (4):

$T_{p b}=P_{C N G}-P_{\text {fuel }} C_{\text {fuel }}-C_{C N G}$,

where

$T_{p b}$ - payback time, $\mathrm{km}$;
$P_{C N G}-$ CNG car price, EUR;

$P_{\text {fuel }}$ - the price of a petrol or diesel car, EUR;

$C_{\text {fuel }}$ - the cost of one kilometre when driving with petrol or diesel, EUR;

$C_{C N G}$ - the cost of one kilometre when driving with $\mathrm{CNG}$, EUR.

\section{RESULTS}

By using Eq. (1) and data from Tables 1 and 3 , the cost per kilometre for different

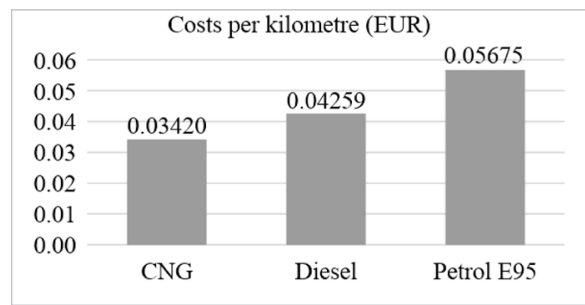

Fig 4. Costs per kilometre by using various types of fuels.

The acquired data demonstrate that the highest price for driving one kilometre is attributed to petrol $(0.06 \mathrm{EUR} / \mathrm{km})$, while diesel is cheaper $(0.04 \mathrm{EUR} / \mathrm{km})$, but $\mathrm{CNG}$ is the cheapest of the three types ( 0.03 EUR/km). According to Eq. (2), driving the CNG-powered vehicle is by $24 \%$ cheaper per kilometre comparing to diesel and by $66 \%$ cheaper to petrol-powered car.

Based on Eq. (3) and data from Tables 1 and 3, a possible mileage for EUR 10 equivalent of fuel was calculated (see Fig. 5).

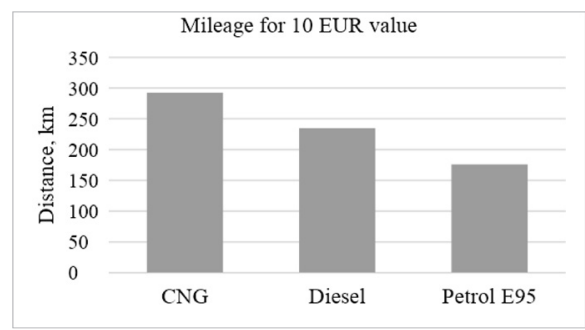

Fig. 5. Possible driving distance for 10 EUR for various types of fuels. fuels was calculated (see Fig. 4).

Results indicate that, from the perspective of fuel choice, the best value for money is ensured by $\mathrm{CNG}$, which provides by far the longest driven distance of $292 \mathrm{ki}$ lometres. At the same time, with diesel it is possible to drive 235 kilometres and with petrol - only 176 kilometres. This again proves clear benefits of CNG usage at a described situation of price differences.

By using Eq. (4), the payback distance was calculated, to recover the difference in vehicle purchase prices between $\mathrm{CNG}$ and petrol-powered vehicles or between $\mathrm{CNG}$ and diesel-powered vehicles (Fig. 6).

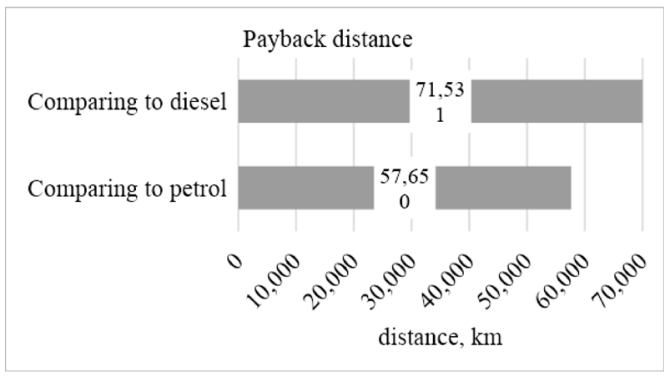

Fig. 6. Payback distance comparing price of $\mathrm{CNG}$ car to a petrol or diesel car.

According to the obtained result, it can be concluded that a purchase of a CNGpowered vehicle starts to pay off after 57650 kilometres comparing to a petrol- 
powered vehicle or after 71531 kilometres comparing to a diesel-powered vehicle. It has previously been mentioned that there are limitations to a CNG vehicle dealer's warranty that should be included. Warranty works for 5 years or mileage limit -100000 kilometres. The results of calculations in both cases show that a CNG-powered vehicle pays back during the warrant period, if at least 57650 kilometres as an alternative of a petrol-powered vehicle or 71531 kilometres as an alternative of a diesel-powered vehicle are driven during this time.

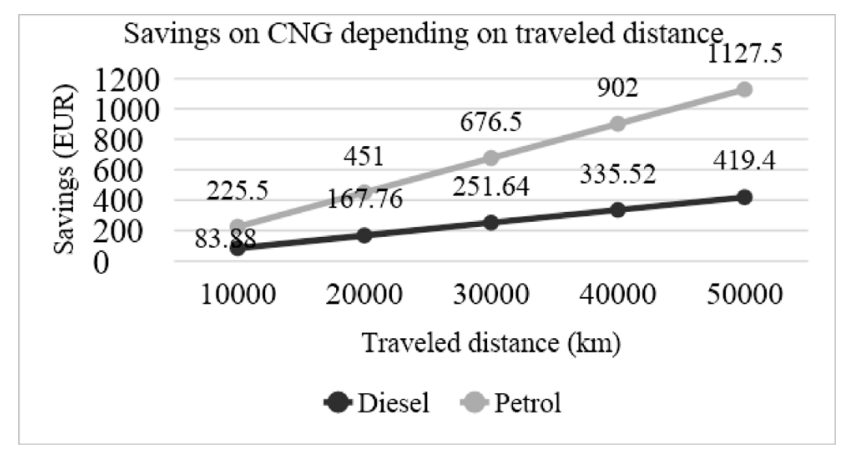

Fig. 7. Savings by using CNG as fuel, depending on distance.

Figure 7, in turn, shows savings, comparing a CNG-powered vehicle with petrol and diesel-powered vehicles, which outline the main trend - the more one drives, the larger the savings and economic benefits a CNG-powered vehicle can bring. By using a CNG-powered vehicle to drive $30000 \mathrm{~km}$, it is possible to save EUR 676.5, comparing to expenses that would occur in case of driving a petrol-powered vehicle. But at $50000 \mathrm{~km}$ even more than EUR 1000 may be saved by using a CNG-powered vehicle instead of a petrol-powered one.

All four calculations show clear economic benefits of a CNG-powered vehicle, if a fuel cost difference is used as the sole economic performance comparison benchmark.

\section{CONCLUSIONS}

Although the most attention has been focused on low emissions of CNG-powered vehicles, especially in densely populated areas, one of the main advantages of $\mathrm{CNG}$ as the road transport fuel remains the price. The calculations presented above clearly indicate the economic benefits of a CNGpowered vehicle, if a fuel cost difference is used as the sole economic performance comparison benchmark.

With fuel prices of a certain retailer, as presented at the end of 2020, the exploita- tion of CNG-powered vehicle was by $24 \%$ cheaper per kilometre comparing to diesel and by $66 \%$ cheaper comparing to a petrol-powered vehicle. In addition, CNGpowered vehicles have smaller operational taxes, since an operation tax is applied based on $\mathrm{CO}_{2}$ emissions, which are lower for $\mathrm{CNG}$ vehicles. The calculation results also indicate that a CNG-powered vehicle pays back during the warranty period, if at least 57650 kilometres as an alternative of a petrol-powered vehicle or 71531 kilome- 
tres as an alternative of a diesel-powered vehicle are driven during this time, so this should be taken into account when choosing the best vehicle option for specific customers' needs.

Since currently $\mathrm{CNG}$ vehicles comprise less than $1 \%$ of all road transport registered in Latvia and taking into account the EU transport and climate policies, $\mathrm{CNG}$ price and possible development of $\mathrm{CNG}$ and L-CNG filling stations, there is a significant potential for the natural gas and RG mobility development in Latvia.

\section{ACKNOWLEDGEMENTS}

The research has been supported by the National Research Programme, project "Trends, Challenges and Solutions of
Latvian Gas Infrastructure Development" (LAGAS) (No. VPP-EM-INFRA-2018/10003).

\section{REFERENCES}

1. Politico. (2017). Decarbonizing Europe's Transport Sector: On the Road to Low Emission Mobility. Available at http:// erticonetwork.com/wp-content/uploads/ 2017/01/Decarbonizing-Europes-transportsector-on-the-road-to-low-emissionmobility-Draft-agenda.pdf

2. Fuel Strategies. (2019). Assessing CNG, $L N G$ and Biomethane. Available at http:// futurefuelstrategies.com/wp-content/ uploads/sites/7/2019/05/MR_FOD_NG_ Apr2019.pdf

3. European Commission. (2017). Summary on National Plans for Alternative Fuel Infrastructure. Available at https://ec.europa.eu/ transport/sites/transport/files/2017-11-08mobility-package-two/summary_of national_policy_frameworks_on_ alternative_fuels.pdf

4. Argonne National Laboratory. (2020). GREET ${ }^{\circledR}$ Model. The Greenhouse gases, Regulated Emissions, and Energy use in Technologies Model. Available at https:// greet.es.anl.gov/

5. Wei, L., \& Geng, P. (2016). A Review on Natural Gas/Diesel Dual Fuel Combustion, Emissions and Performance. Fuel Processing Technology, 142. doi: 10.1016/j. fuproc.2015.09.018
6. Curran, S. J., Wagner, R. M., Graves, R.L., Keller, M., \& Green, J. (2014). Well-toWheel Analysis of Direct and Indirect Use of Natural Gas in Passenger Vehicles. Energy, 75. doi: 10.1016/j.energy.2014.07.035

7. Cabinet of Ministers. (2017). Regulation No. 78 as of 7 February 2017 "Regulations Regarding the Trade and Use of Natural Gas". Available at https://likumi.lv/ta/en/ en/id/289031

8. Khan, M.I., Khan, M.I., Yasmeen, T., Farooq, M., \& Rana, R. W. (2016). Research Progress in the Development of Natural Gas as Fuel for Road Vehicles: A Bibliographic Review (1991-2016). Renewable and Sustainable Energy Reviews, 66 (13640321). doi: 10.1016/j.rser.2016.08.041

9. Janssen, A., Lienin, S. F., Gassmann, F., \& Wokaun, A. (2006). Model Aided Policy Development for the Market Penetration of Natural Gas Vehicles in Switzerland. Transportation Research Part A: Policy and Practice, 40 (4). doi: 10.1016/j. tra.2005.06.006Farzaneh-Gord, M., DeymiDashtebayaz, M., \& Rahbari, H.R. (2011). Studying Effects of Storage Types on Performance of CNG Filling Stations. Journal of Natural Gas Science and Engineering, 3 (1). doi: 10.1016/j.jngse.2011.02.001 
10. Kagiri, K., Zhang, L., \& Xia, X. (2019). Optimal Dispatch of Grid and Natural Gas Generator Power in a Scheduled Compressed Natural Gas Fuelling Station. Chinese Control Conference (CCC), 20292033. doi: 10.23919/ChiCC.2019.8866361

11. Kagiri, Ch., Wanjiru, E.M., Zhang, L. \& Xia, X. (2018). Optimized Response to Electricity Time-of-Use Tariff of a Compressed Natural Gas Fuelling Station. Applied Energy, 222. doi:10.1016/j. apenergy.2018.04.017

12. U.S. Department of Energy. (n.d.). Compressed Natural Gas Fuelling Stations. Available at https://afdc.energy.gov/fuels/ natural_gas_cng_stations.html

13. Hagos, D.A., \& Ahlgren, E. (2018). A Stateof-the-Art Review on the Development of CNG/LNG Infrastructure and Natural Gas Vehicles (NGVs). Technical report Future Gas Project - WP3 Gas for Transport WP3 Deliverable 3.1.1.

14. Sharafian, A., Talebian, T., Blomerus, P., Herrera, O., \& Mérida, W. (2017). A Review of Liquefied Natural Gas Refuelling Station Designs. Renewable and Sustainable Energy Reviews, 69. Available at http://sharafian. weebly.com/uploads/2/9/2/9/29292149/a review_of_liquefied_natural_gas_ refueling_station_designs.pdf

15. Reḳis, J., Šmigins, R., Gailis, M., \& Klāvs, G. (2018). Pētījums par Eiropas Parlamenta un Padomes 2014. gada 22. oktobra Direktīvas 2014/94/ES par alternatīvo degvielu ieviešanu scenārijiem. Rīga: PricewaterhouseCoopers.

16. European Parliament, \& Council. (2014). Directive 2014/94/EU of the European Parliament and of the Council of 22 October 2014 on the deployment of alternative fuels infrastructure. Official Journal of the European Union, L307/1. Available at https://eur-lex.europa.eu/legal-content/EN/ TXT/?uri=celex\%3A32014L0094

17. Gaso. (n.d.). Pašvaldības ar izbūvētu dabasgāzes infrastruktūru. Available at https://www.gaso.lv/karte
18. Dabasgāzes uzpildes stacijas un uzpildes iekārtas, LV NS GS 06-2006/A1:2019. (2006).

19. Bode, I. (2019). Alternatīvās degvielas izmantošana (presentation).

20. Cabinet of Ministers. (2017). On Alternative Fuels Development Plan 2017-2020. Available at https://likumi.lv/ ta/en/en/id/290393-on-alternative-fuelsdevelopment-plan-20172020

21. Jēkabpils autobusu parks. (2019). Jaunie autobusi ir gatavi darbam. Available at https://www.jekabpilsap.1v/lv/jaunumi/ undefined/jaunie-autobusi-ir-gatavidarbam/

22. Soikāns, I. (2020). Par 10 miljoniem eiro Daugavpilī plāno iegādāties jaunus autobusus. Available at https://www.lsm.lv/ raksts/zinas/ekonomika/par-10-miljoniemeiro-daugavpili-plano-iegadaties-jaunusautobusus.a360877/

23. Virši-A. (2021). Gas Stations. CNG. Available at

24. https://www.virsi.lv/lv/uzpildes-stacijas?st $=\&$ search $=\& \mathrm{~s} \% 5 \mathrm{~B} \% 5 \mathrm{D}=14 \&$ location $=$

25. Hokerts, J. (2020). Alternatīvās degvielas no šodienas skatpunkta. Energija un Pasaule, 2/121.

26. Savickis, J., Zemite, L., Jansons, L., Zeltins, N., Bode, I., Ansone, A. ... \& Koposovs, A. (2021). Liquefied Natural Gas Infrastructure and Prospects for the Use of LNG in the Baltic States and Finland. Latvian Journal of Physics and Technical Sciences, 58 (2), 45-63. doi: 10.2478/lpts-2021-0011

27. CSDD. (2019). Likme vieglajiem auto (nodokla likmes no 01.01.2019.). Available at https://www.csdd.lv/transportlidzeklaekspluatacijas-nodoklis/likme-vieglajiemauto-nodokla-likmes-no-01-01-2019

28. Gaso. (2019). Kundzinsalas Southern Project. Technical Requirements. Available at lng.lv

29. Skulte LNG Terminal. (2019). Terminal Design. Available at https://www.skultelng. lv/en/the_project/\#i32 
30. Sināts, M. (2020). Compressed Natural Gas as an Alternative Fuel for Road Transport in Latvia. Master Thesis. Riga: RTU.

31. Birzietis, G., Gulbis, V., \& Šmigins. (2005). Biodegvielu potenciāls, iespējas un šķērṣ̌ıli saistībā ar ES direktīvas 2003/30/EK isstenošanu Latvijā. Available at https:// docplayer.net/22510512-Biodegvielupotencials-iespejas-un-skersli-saistibaar-es-direktivas-2003-30-ek-istenosanulatvija.html

32. European Biogas Association, Gas Infrastructure Europe. (2020). The European Biomethane Map 2020. Available at https:// www.europeanbiogas.eu/wp-content/ uploads/2020/06/GIE_EBA_BIO_2020_ A0_FULL_FINAL.pdf
33. Savickis, J., Zemite, L., Zeltins, N., Bode, I., Jansons, L., Dzelzitis, E., \& Ansone, A. (2020). The Biomethane Injection into the Natural Gas Networks: The EU's Gas Synergy Path. Latvian Journal of Physics and Technical Sciences, 57 (4), 34-50. doi: 10.2478/lpts-2020-0020

34. CSDD. (n.d.). Registrēto transportlīdzekḷu skaits, Registrēto transportlìdzeklı sadalïjums pēc degvielas veida. Available at https://www.csdd.lv/cck?Itemid=327\&c ollection $=$ fails $\&$ file $=$ doc_fails $\& i d=1134 \& t$ ask $=$ download $\& \mathrm{xi}=4$

35. Autobrava Motors. (n.d.). SEAT Leon Technical Specification and Offers. Available at https://modeli.autobrava.lv/ seat/wp-content/uploads/sites/12/2018/07/ seat_leon_2701.pdf 